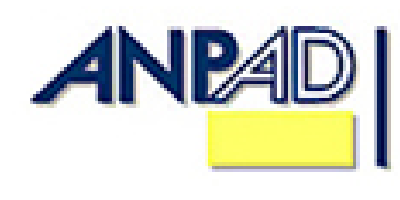

Available online at http://www.anpad.org.br/bar

BAR, Rio de Janeiro, v. 10, n. 3, art. 5, pp. 323-346, July/Sept. 2013

\title{
The Role of Bond Covenants and Short-Term Debt: Evidence from Brazil
}

\author{
Vinícius Augusto Brunassi Silva \\ E-mail address: vinicius.vitio@gmail.com \\ Fundação Getúlio Vargas - EAESP/FGV \\ Rua Ulisses Cruz, 527, apto. 82, bloco B, 03077-000, São Paulo, SP, Brazil. \\ Richard Saito \\ E-mail address: richard.saito@fgv.br \\ Fundação Getúlio Vargas - EAESP/FGV \\ Av. Eng. Luis Carlos Berrini, 1500/42, 04571-011, São Paulo, SP, Brazil. \\ Fernando Carvalhaes Barbi \\ E-mail address: fcbarbi@gmail.com \\ Fundação Getúlio Vargas - EESP/FGV \\ Rua Itapeva, 474, 01332-000, São Paulo, SP, Brazil.
}

Received 17 May 2012; received in revised form 30 January 2013 (this paper has been with the authors for three revisions); accepted 8 February 2013; published online $1^{\text {st }}$ July 2013. Editor's note. Ricardo Pereira Câmara Leal served as Associate Editor for this article. 


\begin{abstract}
This paper examines the role of financial covenants as substitutes for short-term debt and a possible trade off between short-term debt and long-term debt, especially for companies with growth opportunities. Using a sample of 159 corporate bonds issued on the Brazilian Market, we found evidence that: first, financial covenants and short-term debt are substitute tools to minimize agency conflict, as per literature confirming that stronger financial covenants could limit the possible expropriation of debt holders and in exchange debt holders may be willing to lend at longer terms and; second, companies with growth opportunities are willing to exchange shortterm debt for long-term debt under the presence of covenants. Most importantly, this does not seem to be a restriction for financing growth opportunities.
\end{abstract}

Key words: covenants; agency conflict; short-term debt; growth opportunities and leverage. 


\section{Introduction}

Companies with growth opportunities may choose to have an increasing financing leverage. By choosing a higher leverage, many companies choose to finance projects by issuing long-term debt. Long-term financiers may require additional support from shareholders to enter into a long-term financing agreement, such as restrictions on dividend payments, additional leverage, collateral structures and so forth. The use of financial covenants have been used to mitigate possible agency costs between shareholders and debt holders which may lead to suboptimal investments (underinvestment), as suggested by Myers (1977).

In this paper we study how Brazilian companies have chosen to use financial covenants and to what extent this can be used to reduce agency problems. As suggested by Billet, King and Mauer (2007), this paper investigates whether short-term debt and covenants can be used as replacement tools addressing agency costs between owners and creditors. Moreover, several studies have demonstrated that companies with growth opportunities face difficulties in obtaining debt financing, including those by Jensen and Meckling (1976), Myers (1977), Smith and Warner (1979), and Rajan and Zingales (1995). We also investigated whether financial covenants may negatively impact implementation for growth opportunities. The relevance of this study is in identifying the role played by covenants and implications for leveraging and financing growth opportunities. Our contribution is specifically to test hypotheses related to the substitution of financial covenants and short-term debt by providing longterm financing.

The structure of this study proceeds as follows: second section discusses related literature. Third section describes our date set, variables and empirical model. Fourth section provides empirical results and considerations. Final section concludes the paper.

\section{Restrictive Covenants and Short-Term Debt Contributions to Reducing Agency Conflict}

Since the works by Jensen and Meckling (1976), Myers (1977), and Smith and Warner (1979), it has been possible to distinguish costs of value transfer and costs related to agreement mechanisms for mitigating conflicts between shareholders and creditors. Regarding the transfer of value, when managers seek to maximize shareholder value rather than maximize value for the company, there is the possibility of overinvestment or underinvestment in future growth opportunities. Thus, the loss of value to the company resulting from this attitude is characterized as an agency cost. Moreover, mechanisms that help reduce conflict of interests and possible reductions capital cost (debt covenants and short-term debt) also have costs related to its accession. After studies by Jensen and Meckling (1976) and Myers (1977), Smith and Warner (1979) realized that the choice of covenants in a contract may indirectly and simultaneously affect an enterprise's other activities, such as investment decisions, payout policy and leverage.

As mentioned by Billet et al. (2007), although it is possible to reduce such agency conflicts without changing the existing level of debt through the use of short-term debt and restrictive covenants, there are some precautions related to a growth opportunity scenario that a company should take. In a growth opportunity scenario, the use of covenants in debt agreements may limit the opportunities perceived in the future and the use of short-term debt can bring the company liquidity risk problems. As these instruments may limit future investments by firms, the logical solution is to decrease the current level of indebtedness or to use less debt to raise funds in need of funding. Therefore, the expected prediction is that firms with greater growth opportunities are less leveraged. As debt covenants and short-term debt may limit future opportunities, some companies might prefer not to raise debt instruments when they face growth opportunities. That is the reason for predicting that growth opportunities and leverage have a negative relation. In this situation, both covenants and 
short-term debt could be analyzed as possible tools to reduce the negative relationship between growth opportunities and long-term debt.

Studies have shown that reducing debt maturity (i.e. issuing short-term debt) can help treatment of the agency problem. Myers (1977) found that if the debt matures before the exercise growth option, maximizing value to the business can be conducted. Then, it is possible to reduce the incentive for achievement of underinvestment. According to Barclay and Smith (1995), in the event named contracting-cost, investors tend to refuse investment when there is possibility of transferring wealth to creditors. One way to alleviate the problem presented in the contracting-cost hypothesis would be reducing the maturity of debt owned and using short-term debt in subsequent issues.

Billet et al. (2007) followed the results from Johnson (2003) and Childs, Mauer and Ott (2005), and tested the benefit of short-term debt as possibly reducing the negative relationship between leverage and growth opportunities. The result was favorable to the hypothesis of a positive relationship between the tested variables. In other words, short-term debt helps to reduce the negative relationship between leverage and growth opportunities.

As well as short-term debt, bond covenants play an import role in mitigating agency costs and also help reduce the negative relationship between leverage and growth opportunities. Bazzana and Broccardo (2009) argue that a lender will examine the trade-off between problems and costs associated with the use of covenants and benefits arising from their use and decide to include them in debt issuance, since the benefits are higher. Demerjian (2007) studied the choice of financial ratio covenants in debt agreements and found that borrowers with positive earnings, high profitability and low volatility earnings are likely to include covenants in debt agreements related to earnings, such as coverage of the debt to cash flow. On the other hand, borrowers with losses, low profitability and high volatility earnings are likely to use covenants relating to shareholder equity. Besides, Demerjian (2007) also showed that covenants related to leverage are attributed to deals with revolving lines of credit and current ratio covenants are directed to borrowers with high levels of working capital.

Therefore, the use of restrictive covenants can help reduce the negative relationship between leverage and growth opportunities, according to Billet et al. (2007). To verify this premise, they constructed indexes of covenant protection to check both the relationship between growth opportunities and covenants as the relationship between covenants, short-term debt and leverage. Companies with high growth opportunities faced higher agency conflicts. It is possible to infer that benefits resulting from the use of covenants are higher for this type of company. However, companies with these characteristics are also interested in preserving financial flexibility and future financing requirements, which do not allow the inclusion of certain restrictive clauses. Following the authors' argument, this article also predicts a positive relationship between leverage covenant and protection, as the risk of issuing new debt is higher in the presence of increased leverage.

According to the studies mentioned above, we would like to check whether debt covenants and short-term debt play a similar role in addressing agency conflict in Brazil. However, the Brazilian Corporate Bond Market has its peculiarities. Basically, Brazilian companies can raise funds in the local market by issuing Corporate Bonds, commercial papers, private bank loans, stocks and using the support of Banco Nacional de Desenvolvimento Econômico e Social (BNDES), the Brazilian Development Bank.

Anderson (1999) analyzed 50 Brazilian indenture agreements and found specific characteristics for corporate bonds as a possibility to mitigate inflation risk for investors, contingent-maturity mechanisms with periodic opportunities for exit or renegotiation, a paucity of covenants that restrict a debtor's investment, financing and dividend decisions, and self-enforcement mechanisms with the purpose of avoiding reliance on inefficient institutions.

Issuers have flexibility in structuring Corporate Bonds. For example, they may promise a payment according to fixed interest or floating interest (by using some kind of indexation). They can be convertible or nonconvertible into stocks and also include collateral specifications. Filgueira and 
Leal (2001) stated that covenants have suffered changes in Brazilian corporate bonds since 1994. The main explanation for this supports attempts at inflation control, started in 1994 by the Brazilian government. Sanvicente (2002) presented a study which showed that corporate bonds are an important resource of funding not only for public companies, but also for companies that do not have stocks traded on the Brazilian stock market.

Saito, Sheng and Bandeira (2007) studied how covenants have been used to mitigate agency costs between stockholders and bondholders. They corroborate the work done by Filgueira and Leal (2001) mentioned above, found empirical evidence of looser covenants and showed the purpose of corporate bonds issuance; i.e. the destinations of funding raised and reasons for its issuance, such as increased working capital, operation investments and debt terms.

Finally, Silva (2008) applied the hypothesis of optical contractual covenants in the choice of accounting practices. Results demonstrated that the use of covenants has grown in recent years, especially coverage of debt covenants and debt level.

\section{Data, Variable Measures and Model}

We analyzed two databases in order to create our sample. Firstly, it was necessary to collect all available corporate bonds indentures from debentures.com.br, a website maintained by Associação Brasileira das Entidades dos Mercados Financeiros e de Capitais (ANBIMA) which contains detailed information about all corporate bonds issued from 2000 to 2009. After excluding corporate bonds issued by financial firms and finance subsidiaries, we obtained an initial sample of 265 indentures. Nevertheless, many companies that issued corporate bonds during this period are not listed on São Paulo Stock Exchange (BM\&FBovespa), which is a necessary condition for requiring Brazilian companies to publically disseminate their financial data. We thus ended up with a sample composed of 159 corporate bonds corresponding to 82 Brazilian companies. Accounting data for these companies, such as annual balance sheets and income statements, were collected from the Economatica database. Table 1 shows the main features of the corporate bonds analyzed in this study.

Table 1

Characteristics of the Bonds Sample (from 2000 to 2009)

\begin{tabular}{lccccc}
\hline & unsecured & subordinated & $\begin{array}{c}\text { floating } \\
\text { guarantees }\end{array}$ & $\begin{array}{c}\text { real } \\
\text { guarantees }\end{array}$ & Total \\
\hline No. Of Issues & 102 & 20 & 20 & 17 & 159 \\
\% of Total Number & 64.15 & 12.58 & 12.58 & 10.69 & 100 \\
Total offering value & $50,810,901,500$ & $7,925,000,000$ & $3,490,000,000$ & $9,510,448,294$ & $71,736,349,794$ \\
Convertible & 5 & 2 & 0 & 0 & 7 \\
Maturity $\leq 5$ years & 54 & 12 & 19 & 14 & 99 \\
Maturity>5 years & 48 & 8 & 1 & 3 & 60 \\
\hline
\end{tabular}

Note. Source: elaborated by the authors.

\section{Variable measures}

For each corporate bond issued, the prospects showed the incidence of many bond-holder protective and issuer restrictive covenants. Covenants were grouped in major categories according to Billet et al. (2007), since there are multiple covenants for each type of restricted activity.

We grouped the covenants into 10 categories (Table 2): 
Table 2

Covenants

\begin{tabular}{cc}
\hline Number & Description \\
\hline 1 & Accounting-based restrictions \\
2 & Dividend restrictions \\
3 & Reduction of capital \\
4 & Liquidation, dissolution or bankruptcy \\
5 & Change in core business \\
6 & Change in company's structure \\
7 & Transfer of or change in issuer's control \\
8 & Sale, disposal or transfer of assets \\
9 & Default \\
10 & Problems with legal obligations and environmental permits \\
\hline
\end{tabular}

Note. Source: elaborated by the authors.

Detailed explanation of each covenant can be found in Appendix A. Appendix B shows the proportion of each covenant in our sample. We also checked the incidence of each covenant in the corporate bonds according to its classification, secured corporate bonds with real guarantees, floating guarantees, unsecured and subordinated corporate bonds in Table 3. It is easy to see that Covenants 4 (Liquidation, dissolution or bankruptcy) and 9 (default) have high incidences in all indentures. Covenant 7 (Transfer or change in issuer's control) also have high use between the indentures. Indeed, the covenants used the most are related to financial concerns in the analysis of risk prevention by the investor in the loan agreement. One important observation is highlighted in the transfer of control (Covenant 7) and also in the possibilities of mergers and acquisitions (Covenant 6 - Change in company's structure). These covenants are often used together in the indentures. So, information about cash flow and finance and investment decisions seem to be relevant to investors.

Table 3

Covenants in Each Corporate Bond

\begin{tabular}{|c|c|c|c|c|c|c|}
\hline \multirow{2}{*}{$\begin{array}{l}\text { Classification } \\
\text { Covenant }\end{array}$} & \multicolumn{3}{|c|}{ Unsecured } & \multicolumn{3}{|c|}{ Subordinated } \\
\hline & Yes & No & $\begin{array}{l}\% \text { of } \\
\text { total } \\
(102)\end{array}$ & Yes & No & $\begin{array}{l}\% \text { of } \\
\text { total } \\
(20)\end{array}$ \\
\hline Accounting Based Restrictions & 80 & 22 & 78.4 & 20 & 0 & 100 \\
\hline Dividend Restrictions & 67 & 35 & 65.7 & 12 & 8 & 60.0 \\
\hline Reduction of Capital & 34 & 68 & 33.3 & 8 & 12 & 40.0 \\
\hline Liquidation, Dissolution or Bankruptcy & 96 & 6 & 94.1 & 18 & 2 & 90.0 \\
\hline Change in Core Business & 38 & 64 & 37.3 & 4 & 16 & 20.0 \\
\hline Change in Company's Structure & 59 & 43 & 58.0 & 12 & 8 & 60.0 \\
\hline Transfer of or Change in Issuer's Control & 60 & 42 & 58.8 & 15 & 5 & 75.0 \\
\hline Sale, Disposal or Transfer of Assets & 20 & 82 & 19.6 & 7 & 13 & 35.0 \\
\hline Default & 100 & 0 & 100 & 20 & 0 & 100 \\
\hline Problems With Legal Obligations and Environmental Permits & 11 & 91 & 10.8 & 2 & 18 & 10.0 \\
\hline
\end{tabular}


Table 3 (continued)

\begin{tabular}{lcccccc}
\hline Classification & \multicolumn{3}{c}{ Floating guarantees } & \multicolumn{3}{c}{ Real guarantees } \\
\hline Covenant & Yes & No & $\begin{array}{c}\% \text { of } \\
\text { total } \\
(20)\end{array}$ & Yes & No & $\begin{array}{c}\% \text { of } \\
\text { total } \\
(17)\end{array}$ \\
\hline Accounting Based Restrictions & & & & & & \\
Dividend Restrictions & 18 & 2 & 90.0 & 16 & 1 & 94.1 \\
Reduction of Capital & 8 & 12 & 40.0 & 9 & 8 & 53.0 \\
Liquidation, Dissolution or Bankruptcy & 4 & 16 & 20.0 & 2 & 15 & 11.8 \\
Change in Core Business & 18 & 2 & 90.0 & 17 & 0 & 100.0 \\
Change in Company's Structure & 9 & 11 & 45.0 & 4 & 13 & 23.5 \\
Transfer of or Change in Issuer's Control & 14 & 6 & 60.0 & 10 & 7 & 58.8 \\
Sale, Disposal or Transfer of Assets & 7 & 13 & 35.0 & 12 & 5 & 70.6 \\
Default & 6 & 14 & 30.0 & 3 & 14 & 17.6 \\
Problems With Legal Obligations and Environmental Permits & 1 & 19 & 5.0 & 1 & 16 & 5.9 \\
\hline
\end{tabular}

Note. Source: elaborated by the authors.

Another interesting analysis involves correlation measurements. Investors can be worried not only about the covenants used in each corporate bond classification, but also about the linear relationships between these covenants.

According to the covenants' correlation matrix, financial covenants (Accounting Based Restrictions) have significant and strong correlations with dividend restrictions, reduction of capital, change in core business and transfer or change in issuers' control. Moreover, dividend restriction has positive and significant relationships with most covenants analyzed.

We can also identify by the correlation matrix in Table 4 that Covenant 7 (transfer or change in issuers' control) has significant and considerable correlation with issues encompassing control rights and change in company's structure, such as merger and acquisition, for example.

Table 4

\section{Covenants Correlation Matrix}

\begin{tabular}{|c|c|c|c|c|c|}
\hline \multirow[b]{2}{*}{ Covenant } & \multicolumn{5}{|c|}{ Correlation Coefficients } \\
\hline & 1 & 2 & 3 & 4 & 5 \\
\hline 1. Accounting Based Restrictions & 1.000 & & & & \\
\hline 2. Dividend Restictions & $0.3610^{* *}$ & 1.000 & & & \\
\hline 3. Reduction of Capital & $0.2113 * * *$ & $0.1789 *$ & 1.000 & & \\
\hline 4. Liquidation, Dissolution or Bankruptcy & 0.0056 & -0.0153 & 0.0324 & 1.000 & \\
\hline 5. Change in Core Business & $0.2521 *$ & $0.2712 * * *$ & 0.0419 & -0.1349 & 1.000 \\
\hline 6. Change in Company's Structure & 0.1547 & $0.2502 * * *$ & $0.2497 * * *$ & -0.0089 & 0.1098 \\
\hline 7. Transfer or Change in Issuer's Control & $0.2021 * * *$ & $0.1987 * * *$ & $0.2081 * * *$ & 0.1055 & -0.1263 \\
\hline 8. Sale, Disposal or Transfer of Assets & 0.1255 & $0.2321 * * *$ & 0.0691 & -0.1497 & $0.2187 * * *$ \\
\hline
\end{tabular}


Table 4 (continued)

\begin{tabular}{|c|c|c|c|c|c|}
\hline \multirow[b]{2}{*}{ Covenant } & \multicolumn{5}{|c|}{ Correlation Coefficients } \\
\hline & 1 & 2 & 3 & 4 & 5 \\
\hline 9. Default & -0.0105 & -0.1520 & -0.0109 & $0.1899 * * *$ & 0.0106 \\
\hline \multirow[t]{2}{*}{$\begin{array}{l}\text { 10. Problems With Legal Obligations and } \\
\text { Environmental Permits }\end{array}$} & 0.0833 & 0.0950 & $0.3018^{* * *}$ & 0.0791 & 0.0790 \\
\hline & \multicolumn{5}{|c|}{ Correlation Coefficients } \\
\hline Covenant & 6 & 7 & 8 & 9 & 10 \\
\hline \multicolumn{6}{|l|}{ 1. Accounting Based Restrictions } \\
\hline \multicolumn{6}{|l|}{ 2. Dividend Restictions } \\
\hline \multicolumn{6}{|l|}{ 3. Reduction of Capital } \\
\hline \multicolumn{6}{|l|}{ 4. Liquidation, Dissolution or Bankruptcy } \\
\hline \multicolumn{6}{|l|}{ 5. Change in Core Business } \\
\hline 6. Change in Company's Structure & 1.000 & & & & \\
\hline 7. Transfer or Change in Issuer's Control & $0.2502 * * *$ & 1.000 & & & \\
\hline 8. Sale, Disposal or Transfer of Assets & 0.0893 & -0.0246 & 1.000 & & \\
\hline 9. Default & -0.0310 & -0.0949 & $-0.2588 * * *$ & 1.000 & \\
\hline $\begin{array}{l}\text { 10. Problems With Legal Obligations and } \\
\text { Environmental Permits }\end{array}$ & 0.0864 & $-0.1764 *$ & -0.1314 & -0.0094 & 1.000 \\
\hline
\end{tabular}

Note. Source: elaborated by the authors.

$* * *, * *$ and $*$ denote significance at the $10 \%$ level, $5 \%$ level, and $1 \%$ level, respectively.

Analyses of corporate bond clauses and their correlations are important in order to see how corporate bond investors try to choose and combine ways of protecting themselves against default, uncertainty regarding future cash flows, transfer of control, transfer of obligations, changes in core business and other risks. Therefore, we do not have a significant and strong relationships between most covenants and it is clear that covenants are usually combined with other business features. In this paper, we mix variables presented by Billet et al. (2007) and include specific Brazilian considerations to control for possible internal impacts in the choice of covenants.

Covenant 9 (default) shows a significant presence together with Covenants 4 (Liquidation, dissolution or bankruptcy) and 8 (sale, disposal or transfer of assets). This makes perfect sense, since Covenant 8 shows the collateral capacity a company has to face its obligations and Covenant 4 has a strong relationship with default conditions.

The variables used jointly with the covenant index in our analysis are leverage, short-term debt and growth opportunities. Leverage was measured as the book value of total debt (short-term + longterm debt) divided by the market value of the assets, in which the market value is the book value of assets minus the book value of equity plus the market value of the equity. Since we are focusing on the use of short-term debt as a tool with the same purpose of agency problems reduction as covenant index, we measure short-term debt in relation to total debt in a company balance sheet. According to previous works, for example, Billet et al. (2007), the main reference in our study, we use the marketto-book asset ratio as a proxy for firm growth opportunities. These authors followed Adam and Goyal (2003), who argued that the market-to-book ratio is the best proxy for growth opportunities. 


\section{Descriptive statistics}

In accordance with Billet et al. (2007), we started the analysis by using fixed assets, profitability, firm size and volatility as control variables. Nevertheless, volatility was a problem in our estimation due to its insignificance in results and its interference in the results of other variables. Therefore, volatility was not used in our estimation. A proxy used here for fixed assets is the ratio of long-term assets to the book value of total assets. Profitability was specified by the ratio of EBITDA to the book value of total assets.

We also put dummy - years to control for crisis moments (2001, 2002, 2007, 2008 and 2009). By crisis moments we mean difficulties in the Brazilian economy and its stock market due to internet, World Trade Center, and Argentine crises and uncertainties regarding the presidential elections in years 2001 and 2002. Years 2007, 2008 and 2009 represent the recent economic global crises. The amount of issuance was also used as a control variable. Table 5 shows the descriptive statistics of the main variables.

Table 5

\section{Descriptive Statistics}

\begin{tabular}{lccccc}
\hline Variable & Obs & Mean & Std.Dev & Min & Max \\
\hline fixed-asset & 138 & 0.5195 & 0.2106 & 0 & 0.9 \\
leverage & 138 & 34.6043 & 12.4083 & 9.1 & 73.6 \\
lleverage & 138 & 3.4748 & 0.387 & 2.2082 & 4.2986 \\
growth & 117 & 0.7055 & 0.5178 & 0.01 & 2.21 \\
profitability & 149 & 0.0138 & 0.3511 & 0 & 0.2986 \\
firm size & 138 & 14.953 & 1.2885 & 11.7671 & 18.4122 \\
Cov 1 - Accounting based restrictions & 159 & 0.7672 & 0.4238 & 0 & 1 \\
Cov 2 - Dividend restrictions & 159 & 0.5974 & 0.4919 & 0 & 1 \\
Cov 3 - Reduction of capital & 159 & 0.3018 & 0.4605 & 0 & 1 \\
Cov 4 - Liquidation, dissolution or bankruptcy & 159 & 0.9433 & 0.2318 & 0 & 1 \\
Cov 5 - Change in core business & 159 & 0.3459 & 0.4771 & 0 & 1 \\
Cov 6 - Change in Company's Structure & 159 & 0.5974 & 0.4919 & 0 & 1 \\
Cov 7 - Transfer or change in issuer's control & 159 & 0.0591 & 0.4931 & 0 & 1 \\
Cov 8 - Sale, disposal or transfer of assets & 159 & 0.2264 & 0.4198 & 0 & 1 \\
Cov 9 - Default & 159 & 0.9559 & 0.2057 & 0 & 1 \\
Cov 10 - Problems with legal obligations & 159 & 0.9433 & 0.2932 & 0 & 1 \\
Total_indcov & 159 & 0.5421 & 0.1811 & 0.2 & 0.9 \\
indcov & 159 & 0.5890 & 0.2317 & 0.3333 & 1 \\
Weighted - indcov & 159 & 0.6470 & 0.2246 & 0.2392 & 1 \\
short-term debt & 138 & 28.2115 & 21.673 & 1 & 100 \\
\hline
\end{tabular}


Table 5 (continued)

\begin{tabular}{lccccc}
\hline Variable & Obs & Mean & Std.Dev & Min & Max \\
\hline lshort-term & 138 & 3.1074 & 0.6264 & 1.6486 & 4.6051 \\
$\log$ - issued amount & 159 & 19.5168 & 0.892 & 16.9935 & 22.3327 \\
\hline
\end{tabular}

Note. The table reports descriptive statistics from 2000 to 2009. Each variable is measured at the fiscal year-end prior to the year in which leverage, short-term debt and covenant index are measured. Leverage is the book value of total debt divided by market value of assets (book value of assets minus the book value of equity plus the market value of the equity) and lleverage is the leverage logarithm. Short-term debt is a ratio of current liabilities to total debt and lshort-term is its logarithm. Covenant Index (Total_indcov) is the sum of the firm's 10 covenant indicator variables divided by 10 . The next covenant index (Indcov) represents the sum of the 3 significant covenants in the first test, covenants five, six and eight divided by 3 . The last covenant index (weighted-Indcove) is the sum of covenants five, six and eight multiplied by their coefficient $\beta$ in the first analysis, as a proportion of all three covenants $\beta$. The variable growth is the market-to-book ratio (market value of assets divided by the book value of assets). Fixed assets are the ratio of long-term assets to the book value of total assets. Issued Amount is the total offering value for each corporate bond. Covenants 1 to 10 represent each covenant analyzed in this study. Firm size was specified by companies' sales logarithm. Profitability is the ratio of EBITDA to the book value of total assets. Log - issued amount is the logarithm of the total offering value for each corporate bond. Source: elaborated by the authors.

We also tried to control for the influence of corporate governance in the analysis with a dummy variable. Brazil has different levels of governance attributed by BM\&FBovespa for its listed companies. In this case, obligations are not the same and investors may obtain a differentiated level of information for their evaluation. We marked all companies in our sample listed in Novo Mercado and Nivel 2, which are corporate governance segments with higher level of obligations in Brazil, with one and with zero otherwise. In addition, we have the interaction variables growth/short-term and growth/covenant-index, to check the importance of the interactions in reducing a negative relationship between short-term debt and covenants with growth.

We noticed a large difference in the available sample of Brazilian corporate bonds and companies listed on stock markets in comparison to developed countries, especially the USA. Billet et al. (2007) had 1,410 different firms in their sample and we only have 82. However, we could check almost all available corporate bonds issued since 2000 for our sample of 82 companies.

An interesting point to notice before displaying the results is the correlation between covenant indexes, short-term debt, leverage and growth. Table 6 shows a correlation matrix.

Table 6

Variables Correlation Matrix

\begin{tabular}{ccccccc}
\hline & \multicolumn{5}{c}{ Correlation Coefficients } \\
\hline VARIABLES & total_indcove & indcov & weighted_indcov & Lshort-term & lleverage & growth \\
\hline total_indcove & 1 & & & & & \\
indcov & $0.6610 *$ & 1 & & & & \\
weighted_indcov & $0.6618 *$ & $0.9812 *$ & 1 & & & \\
Lshort-term & -0.1209 & -0.089 & -0.1039 & 1 & 1 & \\
lleverage & $0.0439 * *$ & -0.058 & -0.0593 & 0.1245 & & \\
growth & $0.2885 * *$ & 0.0239 & 0.0254 & -0.1861 & 0.0542 & 1 \\
\hline
\end{tabular}

Note. Source: elaborated by the authors.

$* * *, * *$ and $*$ denote significance at the $10 \%$ level, $5 \%$ level, and $1 \%$ level respectively.

When comparing the signs with the US work, indcov and short-term debt have the same sign. However, Billet et al. (2007) show a negative and significant relation between indcov and growth. They argue that companies with growth opportunities chose not to use covenants in their loan 
agreements due to problems with flexibility. We did not see a significant signal in our correlation matrix. Nevertheless, we did see a significant signal in our results. Short-term debt and growth have a negative sign, the same result found in Billet et al. (2007).

\section{Estimation of the empirical model}

In order to estimate the relationships between leverage, short-term debt and the covenant index, we used Seemingly Unrelated Equations (SURE). The SURE model was developed by Zellner (1962) and is appropriate when the endogenous variables are related: the correlation among equations could be due to unobservable firm-specific effects that influence short-term debt, leverage and covenants financing decisions. The system of equations is composed by three regressions that are related as the contemporaneous residuals associated with the dependent variables (leverage, short-term debt and the covenant index). We estimate SURE using the exogenous variables as instruments.

In the empirical analysis we first estimated SURE with short-term debt and leverage as endogenous variables. Together with the variable specified as growth (market-to-book ratio), we used a number of exogenous variables as suggested by Billet et al. (2007). In the leverage and short-term debt equations we included profitability, fixed assets and firm size. In addition to the mentioned variables, we put a dummy for crisis periods and a dummy for corporate governance level (equal to 1 for companies listed in Nivel 2 and Novo Mercado). The purpose of this test was to identify which covenant is statistically significant in order to be part of the covenant index.

The first test can be described as the model below:

lshort-term debt $=\beta 0+\beta 1$ lleverage $+\beta 2$ growth $+\beta 3$ D-crise $+\beta 4$ profitability $+\beta 5$ fixedasset $+\beta 6$ firmsize $+\beta 7$ lshort-termgrowth $+\beta 8 \mathrm{Z}+\varepsilon 1$

lleverage $=\beta 0+\beta 1$ lshort-term debt $+\beta 2$ growth $+\beta 3$ D-crise $+\beta 4$ profitability $+\beta 5$

fixedasset $+\beta 6$ firmsize $+\beta 7$ lshort-termgrowth $+\beta 8 \mathrm{Z}+\varepsilon 2$

in which $\mathrm{Z}$ means a covenant vector: $\mathrm{Z}=$ (covenants $1,2,3,4,5,6,7,8,9$ and 10$)$.

After the first estimation to identify which covenants can be used in the index, we estimated a SURE with lleverage, lshort-term debt and the covenant index as endogenous variables and the variables specified above plus log_issued-amount as exogenous variables in the models.

In accordance with Billet et al. (2007), the model including covenant indexes can be written as:

Lshort-term debt $=\beta 0+\beta 1$ indcov $+\beta 2$ growth $+\beta 3$ D-crise $+\beta 4$ lfirmsize $+\beta 5$ lleverage $+\beta 6$ 1.issued-amount $+\varepsilon 3$

lleverage $=\beta 0+\beta 1$ lshort-term debt $+\beta 2$ growth $+\beta 3$ D-crise $+\beta 4$ profitability $+\beta 5$

fixedasset $+\beta 6$ lfirmsize $+\beta 7$ lshort-termgrowth $+\beta 8$ indcov $+\beta 9$ indcovgrowth $+\beta 10$ $1 \_$issued_amount $+\beta 11$ governance_level $+\varepsilon 4$

Indcov $=\beta 0+\beta 1$ lshort-term debt $+\beta 2$ growth $+\beta 3$ D-crise $+\beta 4$ fixedasset $+\beta 5$ lshorttermgrowth $+\beta 5$ 1_issued_amount $+\beta 7$ governance_level $+\beta 8$ lfirmsize $+\varepsilon 5$

In the robustness check, we created another index using the coefficient $(\beta)$ to weight significant covenants in the first estimation. As can be seen in the results, Covenants 4,6 and 8 were significant and were multiplied by the proportion of their coefficients $(\beta)$ to the sum of the three coefficients. This covenant index was named weighted_indcov. Moreover, we also estimated SURE with an index of 10 covenants, in which we sum the covenants and divide it by 10. This covenant index was named total_indcov.

Billet et al. (2007) explained that the sign between leverage and covenant index may be unclear since covenants have more than one attribute related to leverage. For example, it is possible to use 
covenants in loan agreements of companies with higher leverage level in order to obtain protection; otherwise leverage might be moderated by covenants. In this regard we want to check whether covenants and short-term debt are substitutes. In short-term and indcov equations we predict that these variables have a negative relationship.

Chava and Roberts (2008) and Goyal (2003) argued that high growth firms are typically less likely to include covenants. Billet et al. (2007) confirmed the negative relationship between short-term debt and the covenant index, suggesting that they are substitute tools for reducing agency problems. According to the results presented, we check for Brazil:

Hypothesis: Covenant index and short-term debt are negatively related, which is consistent with the view that they are substitutes in addressing stockholder-bondholder conflicts.

\section{Empirical Findings and Discussion of Results}

Now we shall present our main results with the SURE method. We made different estimations with covenant indexes. First of all, we tried to identify which covenants were relevant in the leverage and short-term debt analysis. Therefore, we put all covenants in regressions and checked the significance of each one of them. After the first analysis, we made a covenant index with the significant covenants. As one can see, Covenants 4, 6 and 8 were significant in the first analysis and were used to construct the first index (the sum of Covenants 4, 6 and 8 divided by 3 ) according to the rationale presented by Billet et al. (2007).

We adopted this method by trying to estimate only relevant covenants for leverage and shortterm debt in Brazil. After that, we constructed another index for the purpose of robustness; i.e. we changed the covenant index with a weight according to its coefficient $(\beta)$ proportion. Finally we checked the results with an index constructed considering all covenants.

There are variables specified as important to explain short-term debt and leverage and all covenants classified from 1 to 10 in this study in Table 7. In the short-term analysis, there is a positive and significant relationship between this variable and leverage, since short-term debt is the ratio of short-term debt to total debt. As mentioned above, short-term debt represents a considerable proportion of Brazilian companies' leverage.

Table 7

Covenant Determinants Estimated by SURE (Test with Individual Covenants)

(1)

Variables

lleverage

Covenant1 - Accounting based restrictions

Covenant2 - Dividend restrictions

Covenant3 - Reduction of capital lshort-term

$0.248 * * *$

$-0.00591$

0.00141

0.0606

$(0.146)$
$(0.0950)$ 
Table 7 (continued)

(1)

\begin{tabular}{|c|c|c|}
\hline & (1) & (2) \\
\hline Variables & 1short-term & lleverage \\
\hline \multirow[t]{2}{*}{ Covenant 4 - Liquidation, dissolution or bankruptcy } & 0.0344 & $-0.336 * *$ \\
\hline & $(0.235)$ & $(0.151)$ \\
\hline \multirow[t]{2}{*}{ Covenant5 - Change in core business } & 0.0980 & -0.0483 \\
\hline & $(0.120)$ & $(0.0789)$ \\
\hline \multirow[t]{2}{*}{ Covenant6 - Change in Company's Structure } & $-0.303 * *$ & -0.0774 \\
\hline & $(0.118)$ & $(0.0795)$ \\
\hline \multirow[t]{2}{*}{ Covenant7 - Transfer or change in issuer's control } & 0.126 & 0.0604 \\
\hline & $(0.119)$ & $(0.0782)$ \\
\hline \multirow[t]{2}{*}{ Covenant8 - Sale, disposal or transfer of assets } & -0.0899 & $0.201 * *$ \\
\hline & $(0.144)$ & $(0.0929)$ \\
\hline \multirow[t]{2}{*}{ Covenant9 - Default } & 0.364 & -0.0583 \\
\hline & $(0.299)$ & $(0.197)$ \\
\hline \multirow[t]{2}{*}{ Covenant10 - Problems with legal obligations } & -0.00597 & 0.0713 \\
\hline & $(0.190)$ & $(0.125)$ \\
\hline \multirow[t]{2}{*}{ Growth } & $-2.198 *$ & 0.260 \\
\hline & $(0.199)$ & $(0.186)$ \\
\hline \multirow[t]{2}{*}{ dcrise } & 0.0685 & $0.209^{*}$ \\
\hline & $(0.125)$ & $(0.0796)$ \\
\hline \multirow[t]{2}{*}{ profitabily } & 2.607 & -1.519 \\
\hline & (1.618) & $(1.063)$ \\
\hline \multirow[t]{2}{*}{ fixedasset } & -0.129 & 0.184 \\
\hline & $(0.279)$ & $(0.183)$ \\
\hline \multirow[t]{2}{*}{ governance_level } & -0.0162 & $0.220^{*}$ \\
\hline & $(0.128)$ & $(0.0813)$ \\
\hline \multirow[t]{2}{*}{ Log_firm_size } & $-0.129 * *$ & -0.0118 \\
\hline & $(0.0536)$ & $(0.0360)$ \\
\hline \multirow[t]{2}{*}{ Lshort-termgrowth } & $0.718^{*}$ & -0.0502 \\
\hline & $(0.0607)$ & $(0.0590)$ \\
\hline \multirow[t]{2}{*}{ 1short-term } & & $0.107 * * *$ \\
\hline & & $(0.0602)$ \\
\hline \multirow[t]{2}{*}{ Constant } & $3.912 *$ & $3.374 *$ \\
\hline & $(1.011)$ & $(0.631)$ \\
\hline Observations & 117 & 117 \\
\hline R-squared & 0.607 & 0.234 \\
\hline
\end{tabular}

(2)

Note. Source: elaborated by the authors.

***, $* *$ and $*$ denote significance at the $10 \%$ level, $5 \%$ level, and $1 \%$ level, respectively. Standard errors are shown in parentheses. 
The variable growth showed a significant and negative relationship with short-term debt. As demonstrated by the theory shown in this paper, a possible explanation for this is that companies which face a panorama of growth opportunities have difficulties in obtaining funding. This negative relationship was also shown by Johnson (2003) and Billet et al. (2007), corroborating the argument.

We also see in Table 7 that firm size and the interaction lshort-termgrowth showed negative and positive significant coefficients, respectively. Firm size was specified as sales logarithm and lshorttermgrowth was created to specify the impact of the interaction of the endogenous variable short-term debt with growth.

Finally, we can see that only Covenants 4 (Liquidation, dissolution or bankruptcy), 6 (change in Company's Structure) and 8 (sale, disposal or transfer of assets) were significant to the leverage and short-term analysis.

Covenant 4 (Liquidation, dissolution or bankruptcy) has a negative relationship with leverage. This might demonstrate a possible difficulty a company can face in the attempt to borrow resources if under this clause's conditions. Covenant 6 (change in Company's Structure) is negatively related to short-term debt. Change in Company's Structure means here that companies are not allowed to be part of other companies or to let others be part of the company who issued the corporate bond (Merger, Split or Privatization, for example). This is the first indication that short-term debt and covenants act as substitutes when seeking to minimize agency conflicts. Covenant 8 (sale, disposal or transfer of assets) has a positive relationship with leverage; this might show a collateral importance to leverage.

However, Billet et al. (2007) mentioned that the sign between leverage and covenants can be unclear, since higher leverage may coincide with more covenant protection, or differently, leverage can be lower in the presence of covenants in outstanding debt issues with future debt finance restrictions. In this study, the significance of Covenants 4, 6 and 8 have more importance in creating subsequent covenant indexes, a condition for proceeding with analysis according Billet et al. (2007). It is also a way of trying to capture only the relevant covenants in the Brazilian context.

Another noteworthy observation is that the leverage equation also shows a positive and significant relationship between leverage and the dummy variables Dcrisis and governance level. Governance level might be explained as a good condition that companies show to become leveraged. The crisis sign is still unclear for us.

In the SURE (using covenant index - Table 8) panel, it is possible to notice the confirmation of this study's hypothesis 1: Short-term debt and the covenant index (indcov) showed a negative and significant relationship. This indicates that they can be seen as substitute tools for reducing agency conflicts. This argument was mentioned by Billet et al. (2007), who explained that covenants and short-term debt help reduce the incentive for the achievement of underinvestment and transference of value among creditors and owners.

Table 8

Covenant Determinants Estimated by SURE (Test Using Covenant Index)

\begin{tabular}{lccc}
\hline & $(1)$ & $(2)$ & $(3)$ \\
Variables & Lshort-term & lleverage & indcov \\
\hline lshort-term & & $0.126^{* *}$ & $-0.110^{*}$ \\
& & $(0.0630)$ & $(0.0376)$ \\
growth & $-1.324^{*}$ & 0.354 & $-0.212^{*}$ \\
& $(0.372)$ & $(0.248)$ & $(0.115)$ \\
\hline
\end{tabular}


Table 8 (continued)

(1)

(2)

\begin{tabular}{|c|c|c|c|}
\hline Variables & Lshort-term & lleverage & indcov \\
\hline \multirow[t]{2}{*}{ Profitability } & & -1.438 & \\
\hline & & $(1.081)$ & \\
\hline \multirow[t]{2}{*}{ Fixedasset } & & 0.273 & 0.129 \\
\hline & & $(0.190)$ & $(0.117)$ \\
\hline \multirow[t]{2}{*}{ Indcov } & $-1.721 *$ & 0.241 & \\
\hline & $(0.473)$ & $(0.231)$ & \\
\hline \multirow[t]{2}{*}{ indcovgrowth } & $1.739^{*}$ & -0.385 & \\
\hline & $(0.582)$ & $(0.284)$ & \\
\hline \multirow[t]{2}{*}{ governance_level } & & $0.239 *$ & 0.0526 \\
\hline & & $(0.0838)$ & $(0.0523)$ \\
\hline \multirow[t]{2}{*}{ Log_issued_amount } & -0.0320 & -0.0229 & -0.0211 \\
\hline & $(0.0973)$ & $(0.0474)$ & $(0.0291)$ \\
\hline \multirow[t]{2}{*}{ Log_firm_size } & -0.0196 & -0.00456 & -0.0112 \\
\hline & $(0.0711)$ & $(0.0404)$ & $(0.0215)$ \\
\hline \multirow[t]{2}{*}{ dcrise } & 0.0672 & $0.180 * *$ & $0.108^{* *}$ \\
\hline & $(0.175)$ & $(0.0817)$ & $(0.0502)$ \\
\hline \multirow[t]{2}{*}{ Lshort-term_growth } & & -0.00270 & $0.0790 * *$ \\
\hline & & $(0.0618)$ & $(0.0371)$ \\
\hline \multirow[t]{2}{*}{ lleverage } & $0.543^{*}$ & & 0.000511 \\
\hline & $(0.186)$ & & $(0.0561)$ \\
\hline \multirow[t]{2}{*}{ Constant } & $3.271 * * *$ & $3.145^{*}$ & $1.377 * *$ \\
\hline & $(1.788)$ & $(0.896)$ & $(0.553)$ \\
\hline Observations & 117 & 117 & 117 \\
\hline R-squared & 0.108 & 0.121 & 0.088 \\
\hline
\end{tabular}

Note. Source: elaborated by the authors.

$* * *, * *$ and $*$ denote significance at the $10 \%$ level, $5 \%$ level, and $1 \%$ level, respectively. Standard errors are shown in parentheses.

The variable growth also showed a negative and significant relationship with short-term debt in our analysis. According to Adam and Goyal (2003) and Billet et al. (2007), there is evidence that market-to-book ratio can be accepted as an excellent proxy for growth opportunities. As such shortterm debt represents a great proportion of Brazilian company indebtedness, it is possible to infer that companies with higher levels of growth opportunities face more difficulties in obtaining short-term funding.

The interaction indcovgrowth can be understood as responsible for minimizing the negative relationship between short-term debt and growth. This result supports the prediction that covenants can help to attenuate the negative effect of growth opportunities in short-term debt. Billet et al. (2007) showed the same result for leverage and the interaction between the covenant index and growth, i.e. it may be considered a support for what was mentioned above. 
In the same direction as the first equation, leverage explains short-term debt with a positive and significant signal. Again, the variable governance_level showed a positive and significant relationship with leverage. As explained before, this variable seems to be relevant for companies to raise funds.

In the indcov equation we confirm the negative and significant relationship between short-term debt and covenants; this helps to strengthen the main hypothesis of this study. The dummy variable for crises remains positive and significant in the leverage and indcov equations.

The interaction lshort-term_growth also helps to attenuate the negative relationship between indcov and growth. This helps to strengthen the hypothesis that short-term debt and covenants are substitutes.

\section{Robustness check}

As mentioned before, in the robustness check we estimated the same model but modified the covenant index. Here we constructed a covenant index with different weights. A balance among Covenants 4,6 and 8 was made via their coefficient $(\beta)$ proportion. We first summed each coefficient $(0.336+0.303+0.201)$ in module, since we were not concerned with their sign relation, but with their ratio (proportion of the coefficient) and then divided each coefficient by the sum. After getting the proportion of each coefficient, we multiplied the proportions by Covenants 4,6 and 8 in the sample.

Modifying the covenant index did not change the previous interpretation. Short-term debt and growth still show a negative and significant sign. In a module analysis, the second coefficient is still higher than the first one. The same happens with the relation between short-term debt and the covenant index. The covenant index coefficient (Weighted_indcov) is higher than the coefficient showed in indcov in a module analysis. The relationship between leverage and short-term debt remains the same. The variable governance_level is still important to the leverage equation.

We also estimated these tests with other control variables. For example, prospect specificities such as the possibility of convergence of debt in stocks and the classification of corporate bonds (unsecured, subordinated, floating or real guarantees) were used in the attempt to capture more significant relationships between variables. Nevertheless, they were not significant. The weighted covenant index estimation is specified in Table 9, below:

Table 9

Covenant Determinants Estimated by SURE (Test Using Weighted Covenant Index)

(1)

\begin{tabular}{lccc} 
Variables & Lshort-term & lleverage & Weighted_indcov \\
\hline Lshort-term & & $0.114^{* * *}$ & $-0.105^{*}$ \\
& & $(0.0629)$ & $(0.0361)$ \\
growth & $-1.387^{*}$ & 0.393 & $-0.192^{* * *}$ \\
& $(0.404)$ & $(0.261)$ & $(0.110)$ \\
profitability & & -1.437 & \\
& & $(1.074)$ & 0.126 \\
fixedasset & & 0.288 & $(0.112)$ \\
& & $(0.189)$ & \\
Weighted_indcov & $-1.807^{*}$ & 0.125 & \\
& $(0.503)$ & $(0.244)$ & \\
\hline
\end{tabular}

(3) 
Table 9 (continued)

(1) (2)

(3)

\begin{tabular}{|c|c|c|c|}
\hline Variables & Lshort-term & lleverage & Weighted_indcov \\
\hline \multirow[t]{2}{*}{ Weighted_indcovgrowth } & $1.685^{*}$ & -0.455 & \\
\hline & $(0.581)$ & $(0.280)$ & \\
\hline \multirow[t]{2}{*}{ Governance_level } & & $0.246^{*}$ & 0.0472 \\
\hline & & $(0.0832)$ & $(0.0502)$ \\
\hline \multirow[t]{2}{*}{ Log_issued_amount } & -0.0396 & -0.0233 & -0.0157 \\
\hline & $(0.0974)$ & $(0.0471)$ & $(0.0279)$ \\
\hline \multirow[t]{2}{*}{ log_firm_size } & -0.0166 & -0.00742 & -0.0145 \\
\hline & $(0.0712)$ & $(0.0402)$ & $(0.0206)$ \\
\hline \multirow[t]{2}{*}{ dcrise } & 0.0870 & $0.199 * *$ & $0.127^{*}$ \\
\hline & $(0.177)$ & $(0.0816)$ & $(0.0482)$ \\
\hline \multirow[t]{2}{*}{ Lshort-term_growth } & & 0.00876 & $0.0737 * *$ \\
\hline & & $(0.0613)$ & $(0.0356)$ \\
\hline \multirow[t]{2}{*}{ lleverage } & $0.532 *$ & & -0.0630 \\
\hline & $(0.186)$ & & $(0.0537)$ \\
\hline \multirow[t]{2}{*}{ Constant } & $3.563 * *$ & $3.275^{*}$ & $1.578^{*}$ \\
\hline & $(1.806)$ & $(0.898)$ & $(0.530)$ \\
\hline Observations & 117 & 117 & 117 \\
\hline R-squared & 0.105 & 0.127 & 0.091 \\
\hline
\end{tabular}

Note. Source: elaborated by the authors.

$* * *, * *$ and $*$ denote significance at the $10 \%$ level, $5 \%$ level, and $1 \%$ level, respectively. Standard errors are shown in parentheses.

In order to check if an index constructed with all covenants has the same relationships presented above, we made an index that is the sum of 10 covenants divided by 10 . Here we sum from Covenant 1 to Covenant 10 independent of their significance in the first equation, as suggested by Billet et al. (2007). The results can be seen in Table 10 below.

Table 10

Covenant Determinants Estimated by SURE (Test Using a Total Covenant Index)

Variables

Lshort-term

lleverage

Total_indcov

\begin{tabular}{lccc} 
Lshort-term & & $0.132^{* *}$ & $-0.0456^{* * * *}$ \\
& & $(0.0607)$ & $(0.0274)$ \\
growth & -0.764 & $0.764 * *$ & 0.0494 \\
& $(0.576)$ & $(0.322)$ & $(0.0834)$ \\
\hline
\end{tabular}

Continues 
Table 10 (continued)

(1) (2)

(3)

\begin{tabular}{|c|c|c|c|}
\hline Variables & Lshort-term & lleverage & Total_indcov \\
\hline \multirow[t]{2}{*}{ Profitability } & & -1.353 & \\
\hline & & $(1.072)$ & \\
\hline \multirow[t]{2}{*}{ Fixedasset } & & $0.314 * * *$ & -0.00173 \\
\hline & & $(0.186)$ & $(0.0851)$ \\
\hline \multirow[t]{2}{*}{ Total_indcov } & $-1.372 * * *$ & $0.697 * *$ & \\
\hline & $(0.744)$ & $(0.333)$ & \\
\hline \multirow[t]{2}{*}{ Total_indcovgrowth } & 0.910 & $-0.986 * *$ & \\
\hline & $(0.931)$ & $(0.413)$ & \\
\hline \multirow[t]{2}{*}{ Governance_level } & & $0.243^{*}$ & 0.0549 \\
\hline & & $(0.0830)$ & $(0.0381)$ \\
\hline \multirow[t]{2}{*}{ Log_issued_amount } & -0.0328 & -0.0311 & -0.0132 \\
\hline & $(0.101)$ & $(0.0468)$ & $(0.0212)$ \\
\hline \multirow[t]{2}{*}{ Log_firm_size } & -0.0202 & -0.0125 & -0.0155 \\
\hline & $(0.0741)$ & $(0.0398)$ & $(0.0156)$ \\
\hline \multirow[t]{2}{*}{ dcrise } & 0.0753 & $0.183 * *$ & $0.0873 * *$ \\
\hline & $(0.183)$ & $(0.0809)$ & $(0.0365)$ \\
\hline \multirow[t]{2}{*}{ Lshort-term_growth } & & -0.0225 & 0.0125 \\
\hline & & $(0.0596)$ & $(0.0270)$ \\
\hline \multirow[t]{2}{*}{ lleverage } & $0.563 *$ & & 0.0205 \\
\hline & $(0.195)$ & & $(0.0408)$ \\
\hline \multirow[t]{2}{*}{ Constant } & 2.906 & $3.142 *$ & $0.997 * *$ \\
\hline & $(1.859)$ & $(0.872)$ & $(0.402)$ \\
\hline Observations & 117 & 117 & 117 \\
\hline R-squared & 0.046 & 0.152 & 0.147 \\
\hline
\end{tabular}

Note. Source: elaborated by the authors.

$* * *, * *$ and $*$ denote significance at the $10 \%$ level, $5 \%$ level, and $1 \%$ level, respectively. Standard errors are shown in parentheses.

We confirm a significant negative relationship between the covenant index and short-term debt, as shown in the first analysis (Table 8). The variable leverage remains with the same sign and is still significant in the short-term equation. The leverage equation maintains significant and with the same sign, but the coefficient is not as strong as it is in the same short-term equation as the previous analysis. The total_indcov equation still shows a significant negative relationship with short-term debt. Once again, the dummies for crises demonstrate a significant and positive relationship with the covenant index and leverage. Another possible explanation for this relationship is that in crisis periods more covenants can be demanded by bondholders, which makes it easier for a company to borrow money (since this meets some creditors' wishes).

Another interesting result is the role of short-term debt in our study. Since short-term debt presents an important way of raising funding in Brazil, it is possible to infer that it has a more 
important role than covenants in reducing agency conflicts. Moreover, short-term debt presents a positive relationship with growth opportunities when covenants and growth are analyzed together.

We notice that the relationship between size and short-term debt is negative and statistically significant in Table 7. This provides some empirical evidence that companies with more assets may have assets in long-term finance controlling for other variables, such as corporate governance levels. On the other hand, smaller companies basically use their current assets (e.g. receivables) for shortterm financing.

This paper might assist financial managers in assessing the trade-off of accessing short-term and long-term financing options. Given the financial covenants in instruments, such as bonds, the financial manager may want to analyze the trade-off of having some limitations or restrictions in dividends, investments and financing in order to access long-term financing with a lower risk of refinancing.

Therefore, we could check in all analyses that the hypothesis that covenants and short-term debt are substitutes seems to be valid. The other significant results are the importance of the variable governance_level dummy for crises and the interactions between the covenant indexes and shortmaturity with growth (with the purpose of minimizing the relationships). Both of these are new in Brazilian studies, for which the equations were estimated by a model that controlled the endogenous problem in the variables leverage, short-term debt and covenants.

\section{Conclusion}

The main purpose of this work was to verify whether short-term debt and restrictive covenants can be considered substitutes or complementary in reducing the agency problem. Furthermore, we intended to investigate the relationship between financial covenants and the characteristics of the studied companies in the sample and to check whether the use of covenants can minimize the negative relationship between short-term and growth opportunities and whether short-term debt minimizes the negative relationship between covenants and growth opportunities, as demonstrated by Billet et al. (2007) with leverage and growth opportunities.

Our results may corroborate the negative relationship between covenants and short-term debt as tools to minimize agency problems. We also found some important control variables, such as corporate governance level, a dummy for crisis periods in the first years after 2000, and the result of interactions between short-term debt and covenant indexes with growth. Based on its proportion in companies' indebtedness levels, in our study short-term debt showed similar results concerning a negative relationship with growth opportunities as leverage did in previous works. In addition to its proportion, we also argue for the importance of short-term debt for Brazilian companies as a limited way of debt funding in Brazil.

Therefore, this paper contributes to the finance literature as the first work to study the endogenous relationship between the variables mentioned above and covenants in Brazil. It also has practical results specified in how covenants are combined between prospectuses. We confirm that covenants and short-term debt can be considered substitutes in addressing stockholder-bondholder conflicts.

Future research can be conducted to analyze whether the hypothesis can be proved empirically in other emerging countries. Another possibility for continuing this study is to identify another method that may be used to treat the endogenous problem specified in this study through the same or other variables. Moreover, it is also important for future research to mention the role of BNDES in relation to companies that face growth opportunities. In this context, it would be interesting to study whether covenants play a similar role in the presence of short-term and long-term leverage. 


\section{References}

Adam, T., \& Goyal, V. K. (2003). The investment opportunity set and its proxy variables: theory and evidence [Working Paper]. Hong Kong University of Science and Technology, Hong Kong, China.

Anderson, C. W. (1999). Financial contracting under extreme uncertainty: an analysis of Brazilian corporate debentures. Journal of Financial Economics, 51(1), 45-84. doi: 10.1016/S0304405X(98)00043-9

Barclay, M. J., \& Smith, C. W., Jr. (1995). The maturity structure of corporate debt. Journal of Finance, 50(2), 609-631. doi: 10.1111/j.1540-6261.1995.tb04797.x

Bazzana, F., \& Broccardo, E. (2009). The role of covenants in public and private debt [Working Papers Series]. Social Science Electronic Publishing. Retrieved from http://papers.ssrn.com/sol3/papers.cfm?abstract_id=1496352. doi: 10.2139/ssrn.1496352

Billet, M. T., King, T. D., \& Mauer, D. C. (2007). Growth opportunities and the choice of leverage, debt maturity, and covenants. The Journal of Finance, 62(2), 697-730. doi: 10.1111/j.15406261.2007.01221.x

Chava, S., \& Roberts, M. R. (2008). How does financing impact investments? The role of debt convenants. The Journal of Finance, 63(5), 2085-2121. doi: 10.1111/j.1540-6261.2008.01391.x

Childs, P. D., Mauer, D. C., \& Ott, S. H. (2005). Interactions of corporate financing and investment decisions: the effects of agency conflicts. Journal of Financial Economics, 76(3), 667-690. doi: 10.1016/j.jfineco.2004.06.012

Demerjian, P. R. W. (2007). Financial ratios and credit risk: the selection of financial ratio covenants in debt contracts [Working Papers Series]. Social Science Electronic Publishing. Retrieved from http://papers.ssrn.com/sol3/papers.cfm?abstract_id=929907

Filgueira, A. L. L., \& Leal, R. P. C. (2001). An analysis of Brazilian bond indentures after the economic stabilization [Working Paper]. Instituto COPPEAD de Administração da Universidade Federal do Rio de Janeiro, Rio de Janeiro, RJ, Brazil.

Goyal, V. K. (2003). Market discipline of bank risk: evidence from subordinated debt contracts. Journal of Financial Intermediation, 14(3), 318-350. doi: 10.1016/j.jfi.2004.06.002

Jensen, M. C., \& Meckling, W. H. (1976). Theory of the firm: managerial behavior, agency costs and ownership structure. Journal of Financial Economics, 3(4), 305-360. doi: 10.1016/0304$405 X(76) 90026-X$

Johnson, S. A. (2003). Debt maturity and the effects of growth opportunities and liquidity risk on leverage. Review of Financial Studies, 16(1), 209-236. doi: 10.1093/rfs/16.1.209

Myers, S. C. (1977). Determinants of corporate borrowing. Journal of Financial Economics, 5(2), 147-175. doi: 10.1016/0304-405X(77)90015-0

Rajan, R. G., \& Zingales, L. (1995). What do we know about capital structure? Some evidence from international data. Journal of Finance, 50(5), 1421-1460. doi: 10.1111/j.15406261.1995.tb05184.x

Saito, R., Sheng, H. H., \& Bandeira, M. L. (2007). Governança corporativa embutida nas escrituras de debêntures emitidas no Brasil. Revista de Administração da USP, 42(3), 280-292. 
Sanvicente, A. Z. (2002). A evolução recente do mercado primário de debêntures. Revista da CVM, (34), 63-70.

Silva, A. H. C. (2008). Escolha de práticas contábeis no Brasil: uma análise sob a ótica da hipótese dos covenants contratuais (Tese de doutorado). Universidade de São Paulo, São Paulo, SP, Brasil.

Smith, C. W., \& Warner, J. B. (1979). On financial contracting: an analysis of bond covenants. Journal of Financial Economics, 7(2), 117-161. doi: 10.1016/0304-405X(79)90011-4

Zellner, A. (1962). An efficient method of estimating seemingly unrelated regressions and tests for aggregation bias. Journal of the American Statistical Association, 57(298), 348-368. doi: 10.1080/01621459.1962.10480664 


\section{APPENDIX A}

\section{Covenants}

\section{Covenant 1: Accounting Based Restrictions. Ratio covenants.}

a) (DEBT/EBITDA): Variable Debt means the sum of all consolidated debts from a company. Some companies used net debt instead of total debt. EBITDA is the earnings before interest, depreciation and amortization.

b) (Interest Coverage Index): This index is the proportion of EBITDA divided by net debt.

c) (Short-term debt / EBITDA): Another financial covenant to maintain the firm under certain conditions. Short-term debt means all debts that mature within one year or less.

d) (Debt/Equity): This covenant specifies a limit of indebtedness measured by the proportion of Debt (all debts) to Equity.

e) (Other Financial Covenants): Here we group financial covenants that do not appear often in the prospects. For example, a minimum level of net worth, limits for bank debts and bank debts divided by net worth.

f) (EBITDA/CAPEX): A covenant that specifies a measure of how a company can cover its capital needs using internal funding.

\section{Covenant 2: Dividend Restrictions.}

(Dividend Restrictions): This covenant stipulates a limit of dividends that must be paid or a prohibition of dividend payments.

\section{Covenant 3: Reduction of Capital.}

The issuer of the corporate bond must not reduce their capital/net worth in the company.

\section{Covenant 4: Liquidation, Dissolution or Bankruptcy.}

The company must not allow its own Liquidation, Dissolution or Bankruptcy.

\section{Covenant 5: Change in Core Business.}

It is not allowed to change the main purpose of a company. It has to do what it is widely known to do for clients.

\section{Covenant 6: Change in Company's Structure;}

a) Merger, Split or Privatization: Companies are not allowed to be part of other companies or to let others be part of the company who issued the corporate bond.

b) Change in legal structures: Companies must also maintain their legal structures. In Brazil, we have corporations with their capital listed on a stock market and corporations that are not listed on stock markets that can issue corporate bonds. This covenant does not allow change in companies' legal structures and, therefore, the corporations that are not listed on a stock market at the moment of the loan agreement cannot try to participate in the stock market while corporate bonds exist. 


\section{Covenant 7: Transfer or Change in Issuer's Control.}

The company that issues a corporate bond cannot change its controlling stockholders and its main directors.

\section{Covenant 8: Sale, Disposal or Transfer of Assets.}

Companies are not allowed to sell, negotiate or use the companies' assets for other purposes.

\section{Covenant 9: Default.}

a) The company must pay all its debts in time.

b) Lowering the credit rating: In accordance with a rating agency, companies cannot have a reduction in their risk classification.

\section{Covenant 10: Problems with legal obligations and environmental permissions.}

All licenses and work contracts that a company has must be in perfect condition. The company cannot be part of environmental problems and must face all their legal obligations. 


\section{APPENDIX B}

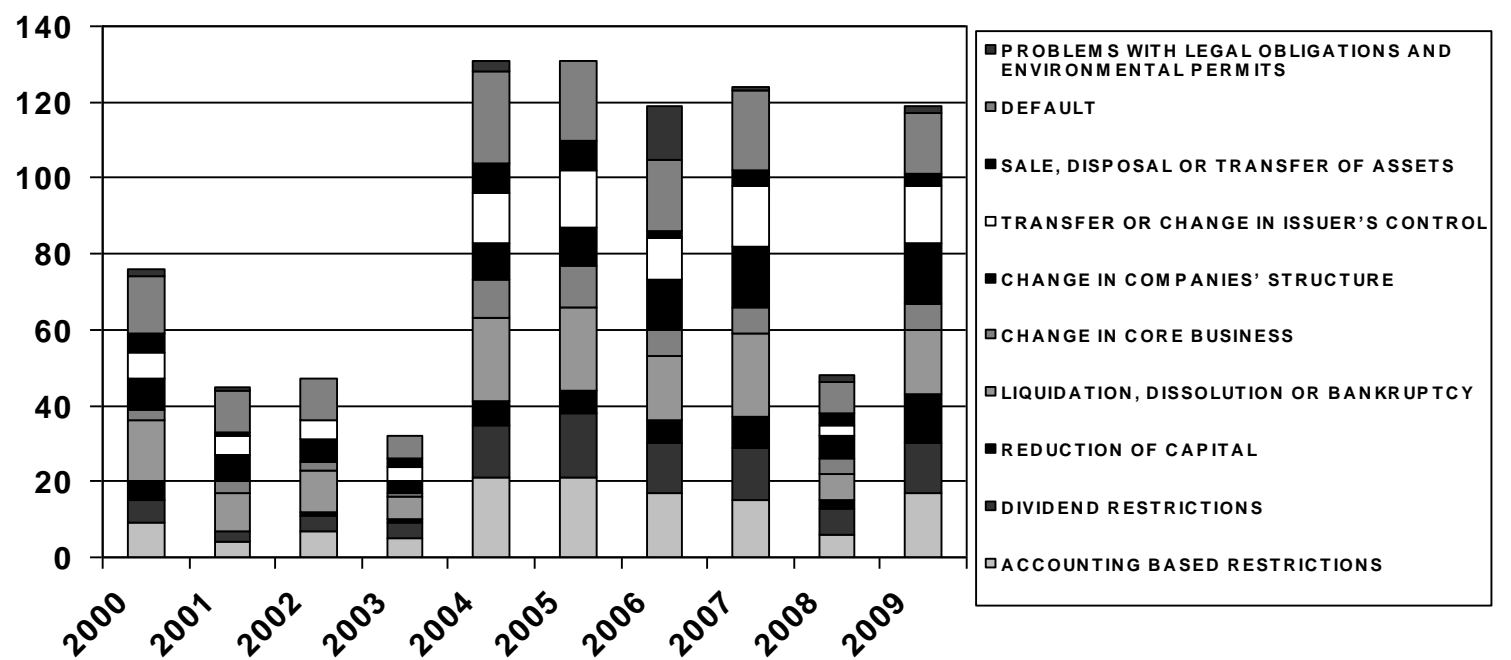

Figure 1. Covenants in the Sample (2000 - 2009).

This graph shows the proportion of each covenant of our sample since 2000. Source: elaborated by the author.

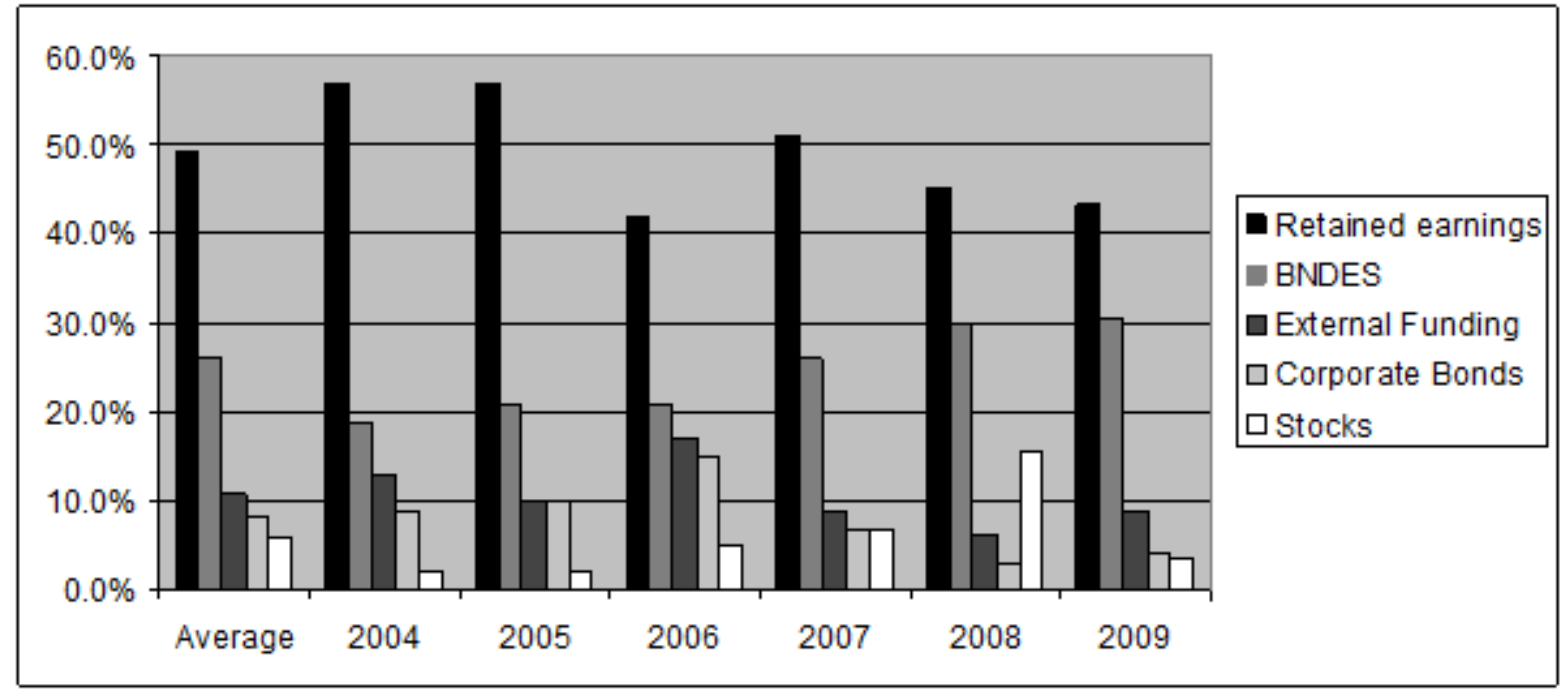

Figure 2. Brazilian Companies' Funding from $2004-2009$.

This graph shows Brazilian companies' funding from $2004-2009$.

Source: Coutinho, L. (2010). Desafios do financiamento a longo prazo [Almoço-Palestra]. São Paulo: Instituto Brasileiro de Executivos de Finanças. Retrieved from

http://www.bndes.gov.br/SiteBNDES/export/sites/default/bndes_pt/Galerias/Arquivos/empresa/download/apresentacoes/Cou tinho_DesafiosFinancLP_ago10.pdf 